\title{
The Leading Role of the Language Phenomenon in Brain Activity
}

\author{
Minaxanum Hajiyeva \\ Azerbaijan University of Languages, Baku, Azerbaijan \\ Lehrerin81@mail.ru
}

\begin{abstract}
One of the most prime examples of a multidisciplinary field, Cogntive Lingusitics explores language as a cognitive mechanism in the coding and transformation of information. On the other hand, Neurolinguistics, combining two major sciences and studying the functional course of consciousness, deals with cognitive processes and the relationship between the brain and them. In the scientific development of its history, a number of different research areas related to the study of the functionality of the brain hemispheres are noteworthy. The different functions in the brain mechanism benefit from cognition, concepts, conceptsphers, and other necessary elements. Cognitive linguistics dealing with the illumination of these functions tries to highlight the aspects of language activity, seeing as how one of the important keys to reflecting the programmed mechanism of the brain is language-related activities. The main purpose of the research is to determine the relationship between functionality of the language phenomenon and the brain mechanism.
\end{abstract}

Keywords: Cognitive linguistics, brain hemispheres, broca`sarea, wernicke`s area, language center, brain mechanism

\section{Introduction}

There are different fields of enquiry, the object of which is language, conducting their research each according to different methods. Even among these sciences, convergent fields that combine their denominators and achieve different results with interesting research should be especially noted. Joint research in such different fields yields more interesting results. In the words of Academician Kamal Abdullah, perhaps these relations are related to isomorphism, which has a great universal nature: Wittgenstein also bases this principle on his "Logical-Philosophical Treatise" and considers isomorphism in general as a correspondence between reality (the world) and language, uniting their boundaries" (pp.1,38). One such multidisciplinary field is cognitive linguistics. "Cognitive linguistics studies the complex relationship 
between language and thought" (p.8). As one of the convergent sciences, it is considered to be one of the fields that studies the complex relationship between common denominators and language and thought. Cognitive linguistics studies language as a cognitive mechanism that plays a role in coding and transforming information. Researchers working in this field study the primary role of language in human life, on the one hand, and the relationship between the human factor and language activity, on the other. However, above all, they are interested in the mechanism of the human brain. Since the mental processes that take place during acceptance and perception, the forms and types of mental representation are similar to the computer image, the process of studying this natural mechanism is organized in accordance with the computer structure. According to him, "mental events have features that cannot be imagined in the" scientific "world" (p.11).

That is, science should be engaged only in the study of visible phenomena. However, again, the points related to the brain and its mechanism have always been the focus of researchers, and the interesting results obtained in connection with these events have survived to the present day. Even as we turn the pages of the history of science, it is clear from the skulls that have undergone a number of neurosurgical operations since ancient times that the roots of interest in this field go very deep. A general look at modern scientific research based on such data reveals several exciting conclusions about facts such as the total capacity of the neural network, the number of neural connections, the activity and deletion of memory, and implants. Despite the enormous amount of research that has been done over the centuries, there are still some unanswered questions that remain unknown to humankind.

Interest in such unanswered topics led to the emergence of neurolinguistics, a young field. Neurolinguistics, a combination of two great sciences studying the functional development of consciousness, has a special field of interest as part of psycholinguistics. The tasks of neurolinguistics include the study of the relationship between language and cognitive procedures and the brain. Researchers in this field are particularly interested in the activity of speech in human behavior. Because it is through language that it is possible to determine the form in which realities are reflected in the brain, the relationship between speech activity and cognitive mechanism, and a number of interesting facts about human behavior. For a while, neurolinguists tried to study their objects of study without touching the brain. However, a number of obscure issues were later clarified thanks to the brain factor. Studies of patients with cerebral palsy have shown that the brain is made up of blocks that serve different functions (Picture 1). 


\section{Brain and its hemispheres}

What is the brain? What is its phenomenal mechanism? How is the functional activity of the cerebral hemispheres organized?

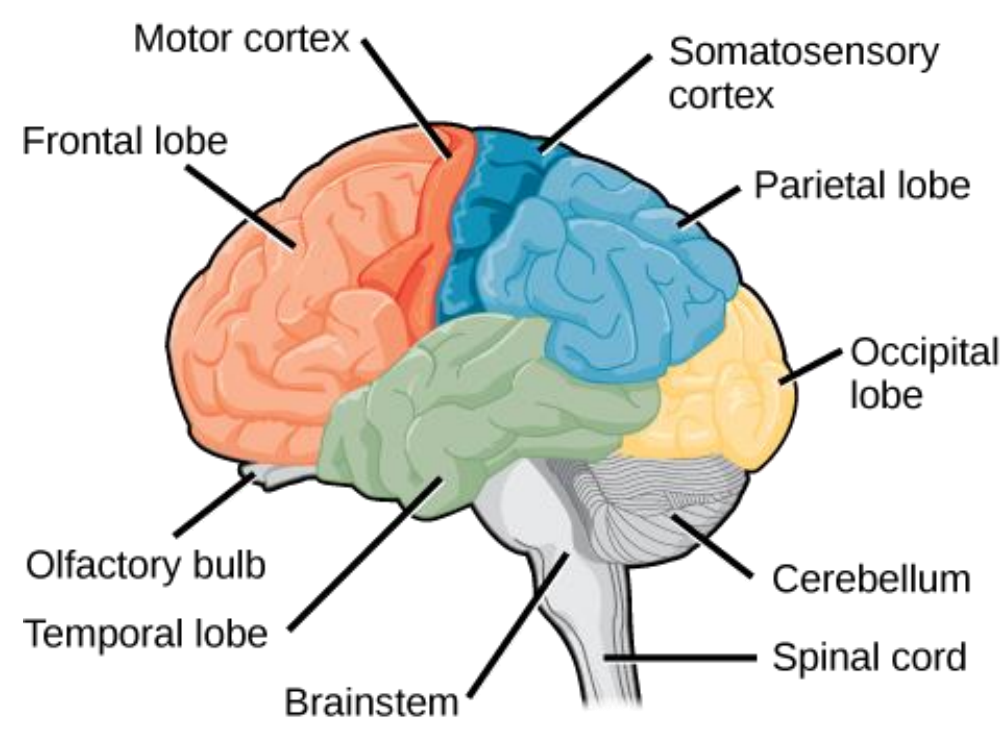

Picture 1. Anatomy and functional areas of the brain (Source: Wikimedia Commons)

“... Inside a bone box, between elastic mattresses, this gray-pink substance weighing 1,200-1,400 grams is connected to 86 nerves on each side of the human body." (pp.2,9). As science advances, the brain, which is not so large in size and weight, but controls the human being in an unimaginable way, is being studied from a different perspective. The discovery of the gray matter that forms the basis of the brain is associated with the name of a scientist named Franz Josef Gall. He linked mental functions to centers localized in certain parts of the brain. He was a phrenologist in the early 19th century who sought to determine brain activity based on the skull (p.6). Although Gall, who paid particular attention to the cerebral hemispheres, failed to detect the activity of the brain, for the first time he assessed the leading role of the gray matter of the cerebral hemispheres, and also developed a map of the localization of mental abilities.

Until functional differences between the hemispheres were identified, there were even moments in certain sections of history when the right hemisphere of the brain was considered unnecessary. Doctors considered it an unnecessary hemisphere that hindered the work of the left hemisphere. "We live in a society where logical thinking 
is highly valued. People whose left hemisphere is dominant, achieve great success, children whose left hemisphere is dominant successfully perform arithmetic activities, study diligently and are distinguished by diligence, getting excellent grades in school. But children whose right hemisphere is dominant prefer to dream and invent different stories by looking at the clouds instead of studying and are considered bad students because their efforts are not encouraged by our society." (pp.5,28). Over time, it became clear that the work of the right hemisphere, which once "hindered" the activities of the left hemisphere, is more important to the makings of a creative person. The right hemisphere, the source of creativity, is formed due to the activity of speech and writing skills.

It is known that the number of right-handed people in the world is many times higher than the number of left-handed people. The life activities of both types of people are somewhat different from each other. The reason for this difference is the activity of the cerebral hemispheres. According to the " $X$ " structure, the left hemisphere controls the speech apparatus of right-handed people, and although the left hemisphere is taken as the main part, it cannot interfere with the lateralization of the right hemisphere. The left hemisphere, which is constantly active due to the activity of the right hand, shapes human life in the direction of its functions. The activity of left-handed people, which is very rare, is related to the functional course of the right hemisphere. The creative activity of this type of people is also associated with the activity of the right hemisphere. "Both in sleep and when our brains are engaged in something completely different, they are the result of the creation of the right hemisphere, which makes plans for the future" (p.10).

In any case, among other activities related to human behavior, language-related aspects are activated by the interaction of both hemispheres. Although the action of language activity in most people is located in the left hemisphere, the logical analysis and thinking in the right hemisphere are regulated by language. Considering the role of the language factor in the formation of the hemispheres, its aspects of thinking come to the fore. In this regard, the relationship between language and thought has been interpreted differently by researchers. According to some, thoughts are possible only on the basis of language, that is, thinking is impossible without language. For example, according to the German linguist A. Schleicher, "just as the soul does not exist without matter, so thought does not exist without language." That is, even when a person is thinking, he/she silently analyzes his/her thoughts through language, and finally encodes the result of his/her thoughts in the form of audio information (pp.13,4). According to Müller, "language and thought are inseparable: their isolation means death for both." Based on this claim, it is impossible to accept the concepts of language and thought in isolation from each other. Both activities can always be productive in a relationship (pp.7,47). I. Stalin's approach in this area is 
also very interesting. According to his commentary on Marxism and the Problems of Linguistics, he does not accept the idea that thought exists in the human brain without language, without material, and repeatedly emphasizes that it belongs to idealists (pp.12,39). According to B. Sergeyev, speaking from another position, "If most people think with words, it is not always typical for scientists. Many eminent mathematicians think with visual, sometimes moving images ... This has contributed to the further development of the right hemisphere and the creation of a system of special signs for internal speech which later turned them into eminent scholars, completely protected them from the traditional healthy common sense or their verbal reasoning from the skeptical interference of the left neighbor and was used in the creative process" (p.10). Considering the analysis of these two positions, we can come to some evidence for the functionality of the hemispheres. It can be assumed that the hands that first perform the writing skills form the functions of the hemispheres that control it. At the same time, the governing hemisphere of the constantly active party is more developed. However, the relationship between the hemispheres should not be overlooked here.

In the second half of the 19th century, a scientist named Paul Broca brought to the public's attention the facts he had identified by autopsy after the death of a patient suffering from a speech impediment. Based on these facts, the patient had lesions in the left hemisphere of the forehead. According to Dr. Broca, the area involved in the conversation is in the frontal lobe of the left hemisphere. In addition to P. Broca's (1824-1880) conclusion, another scholar, K. Wernicke (1848-1905), also discovered another area of conversation. These two zones, located on different sides of the left hemisphere, are considered to be the zones associated with the origin and reception of speech. One of these zones was named after scientists such as Broca's area and the other Wernicke's area. Previously, it was thought that Broca's area dealt only with the automatic creation of speech, while Wernicke's area dealt with the analysis of information. However, it later emerged that without Broca's area, Wernicke's area would not be able to analyze any information.

There is a nuance that draws our attention here: are these centers, which serve conversation and information analysis, always located in the left hemisphere of the brain? Approaching the above-mentioned evidence, it can be concluded that the location of these centers is determined on the basis of the control of a hand accustomed to writing. That is, it is very likely that, according to the writing habits of the left-handed person, his/her speech-related activities, as well as those of Broca's area and Wernicke's area, are located in the right hemisphere. However, regardless of the location of these centers, their mutual exchange must be assumed as a crucial precondition. Most simple tasks require the functions of both hemispheres. Both the right and left hemispheres are made up of a large number of interconnected neurons. 
“... The brain is a system similar to the electrical circulation of millions of neurons but connected by chemical compounds" (pp.2,16). Here, the connection between millions of existing cells takes place through these chemical reactions. "Communication between nerve cells occurs through the passage of chemicals through small synaptic spaces" (pp.2,16).

\section{The functionality of hemispheres}

In the subsequent scientific development of history, research on the functionality of the cerebral hemispheres has become more widespread. There are many interesting research results on the joint activity and specific functionality of the hemispheres. As K. Pribram, who considers the brain to be a holographic structure, noted: "The brain is made up of neurons separated by structurally and functionally different membrane layers" (pp.9,17). According to this information, the hemispheres provide other higher functions. It was claimed that the left hemisphere was "analytical", "logical", the right hemisphere was "intuitive", "holistic". It is not enough to have only one logical apparatus to understand any problem creatively. The key element here is intuition, which is an important function of the right hemisphere. During the activity of the right hemisphere, operations are carried out in secret. The agent can easily create and destroy different associations. This secret activity takes place independently of the left hemisphere, and at this point the left hemisphere cannot interfere with the final result. The main problem here is the use of hemispheres by cognitive parameters. Parties that perform different functions in the brain's mechanism make unique use of cognition, concepts and other necessary elements.

"Because the right and left hemispheres of the brain perform different functions, each of them is a separate area of specialization. The right side of the brain, in addition to performing broad and complex functions such as vision and attention, also controls the left side of the body. The left side of our brain controls the right side of our body and our speech. Although speech reminds us of the activity of the tongue and lips, the left hemisphere of the brain controls these functions, as behaviors such as eating and drinking, various facial expressions, and facial expressions are also related to the tongue and lips. According to recent research by some scholars, abstract concepts such as language learning, word formation, grammar and speech are also controlled from this part of the brain along with the speech center" (pp.5,35). The right hemisphere copes well with non-verbal and communication tasks. It mainly controls the sensory function of the left side of the body, and it also controls situations such as cognitive recognition of objects and time, emotional humor, and depression. The 
left hemisphere also provides the sensory function of the right hemisphere and is responsible for scientific and mathematical knowledge and logic (pp.5,31).

In our opinion, language activity is one of the important keys to seeing the programmed mechanism of the brain. After all, it is through language that it is possible to estimate the size of the brain of the person ahead. Because it is individual, the sentence reveals the whole inner world of the individual like a mirror (pp.1,301). Rodger Sperry was one of the researchers trying to study this mechanism in the context of language activity. His colleagues who joined his subsequent research are considered to have taken the first step in this research. Dr. Sperry, who made interesting hypotheses about the mechanism of the brain, aroused great interest in Dr. Michael Gazzaniga. In 1960, he joined R. Sperry's scientific activity and signed a number of researches. (16). It should be noted that R. Sperry had previously made a number of interesting discoveries about animals during his individual research. He then went further in his work with colleagues, suggesting that the "language center" was located in the left hemisphere, based on research by people with brain diseases. The researchers tried to find out the points of independent activity of the cerebral hemispheres. With an interest in this field, they paid special attention to perception, vision, and other brain functions in cerebral hemisphere operations at the California Institute of Technology. In an operation on a patient with severe epilepsy, the speech center in the left hemisphere and the corpus callosum, which transmits analysis signals and regulates vision in the right hemisphere, did not work. In the course of this study, 10 patients were operated on that eve, and only 9 of them agreed to participate in the study. After the severance of the corpus, the intellectual and emotional field of each patient remained intact. Even the results showed that the patients showed extraordinary intelligence. To analyze cognitive ability, researchers developed three types of tests: tactile, visual, and vocal comprehension. The results of their research showed that both hemispheres have different functions. It turned out that the left hemisphere is a functional area for writing, speaking, arithmetic, reading and language. Problem solving, facial recognition, acting with symbols, and art belong to the functional area of the right hemisphere.

As a follow-up to his research, R. Sperry redefined the imbalance of hemisphere asymmetry based on the cases of speech and cognitive impairment observed in patients with schizophrenia. Numerous observations have shown that people with left hemisphere damage lose the ability to speak. According to the results of the experiment, R. Sperry and his colleagues finally proved the functional asymmetry of the right and left hemispheres of the human brain. It turned out that all types of semiotic activity are distributed between the right and left hemispheres, and the "language center" consists of a special block located in the left hemisphere.According to Sperry, although the "language center" is located in the 
left hemisphere, Homo loquens can perform coding-decoding, arbitrary-involuntary speech procedures thanks to both hemispheres. As a result of his research, R. Sperry was awarded the Nobel Prize in Medicine in 1981 for his discovery of the functional nature of the cerebral hemispheres (p.17). The findings of R. Sperry and M. Gazzaniga's joint work were published in the journal Scientific American in 1967 and served as a source for a number of new studies.

R. Sperry continued this research until his death (1994). M. Gazzaniga is still continuing his research. Their discoveries in this field have sometimes been criticized and debated in the course of scientific development. For example, in 1980, Carre Levis, a psychobiologist at the University of Chicago, suggested that if the hemispheres had different functions, they should be linked rather than separated. Because no human activity takes place unilaterally, using the brain. Because the two hemispheres of the cerebral cortex are connected to the corpus callosum, although each hemisphere has different functions, communication, and coordination between the two hemispheres is absolutely essential (p.15). A 1998 study by Hommet and Billiards also cast doubt on Sperry and Gazzaniga's views. They found that the severed corpus during the experiment did not occur in children in the womb, but there was still an exchange of information between the hemispheres and that such children had subcortical connections (p.14). Despite the existence of conflicting views, research in this area continues dynamically. Research suggests that activities in both hemispheres are relatively straightforward.

\section{Conclusion}

Cognitive linguistics, which explores the relationship between language and thought, has quickly attracted the attention of a wide audience as a convergent field. The main focus of this research is on the study of coding and decoding features based on the brain mechanism. In fact, for many years the study of brain and language problems was based solely on neurosurgery. The subsequent development of neurolinguistics led to the elimination of these difficulties and the non-surgical study of a number of points. According to neurolinguistic studies, brain activity weighing 1,200 to 14,000 grams is controlled by 86 nerves connected to different parts of the body. These nerves are distributed between the right and left hemispheres in terms of activity. Within this activity, language-specific functionality is mainly located in the left hemisphere. Due to this localization, the right side of the body, especially the right hand, which is accustomed to writing, is controlled. According to the results of our extensive research, the functionality of a language cannot be limited to just one hemisphere. Because, despite the fact that the process of logical analysis and 
thinking is located in the other hemisphere, it is closely linked with the activity of language.

The literature visited and summed up in this paper has far-reaching implications for such diverse areas as how the brain is involved in creative and cognitive reasoning skills (Glen et al, 2016) and even multilingual first language acquisition (Shahiditabar, 2016) and many others learning and development phenomena.

\section{References}

Abdulla, K. (2017) ' Kitabi-Dədə Qorqud' poetikasına giriş. Dansökülən variant.', Bakı.

Gelen, I., Duran, V., \& Ozer, B. (2016) Investigation of Hypothetico-Creative Reasoning Skills of Teacher Trainees in Terms of Their Thinking Styles. Khazar Journal of Humanities and Social Sciences. 19 (3), 82-110. DOI: 10.5782/2223$\underline{2621.2016 .19 .3 .82}$

İhsanoğlu, I., H. (2008) 'Beynimizin sirləri', Bak1.

Məmmədov, A. \& Məmmədov, M. (2010) 'Diskurs təhlilinin koqnitiv perspektivləri', Bakı. Veysəlli, F. (2016) 'Koqnitiv dilçilik', Bakı.

Зденек, М. (1997) 'Развитие правого полушария', (Углубленная программа высвобождения сил вашего воображения). Пер. с англ. Москва.

Кирилл, Н. (2007) 'Академия мёртвых наук, журнал «Деньги», г., N 4

Мюллер, Ф. М. (2011) 'Наука о мысли', Пер. с английского. Изд. 2-е, Москва.

Попова, З. Д. \& Стернин, И. А. (2007) 'Когнитивная лингвистика', Москва.

Прибрам, К. (1975) 'Языки мозга', Москва.

Сергеев, Б.Ф. (1984) 'Ум хорошо...', Москва.

Серль, Дж. (1984) ‘Сознание, мозг и наука. Посвящается Дагмар’, Harvard University Press (Перевод и примечания А.Ф.Грязнова, 1993)

Сталин, И. (1955) 'Марксизм и вопросы языкознания', Москва.

Кулиша, П.А. (1864) 'Шлейхер, А. Теория Дарвина в применении к науке о языке', Публ. послание д-ру Эрнсту Генкелю, э. о. проф. зоологии и дир. Зоол. музея при Иен. ун-те, Августа Шлейхера. СПб.: тип..

Juliet, A. (2014) 'The Neuroscience of Mindfulness', Midfulnet.

Levy, J. \& Trevarthen, C. (1995) 'Metacontrol of hemispheric function in human split-brain patients', New York Plenum

Gazzaniga, M. (1967) 'The Split Brain in Man', America.

Shahiditabar, M. (2016). Acquisition of spatial adjectives in the case of a four-year-old child knowing Azerbaijani Turkish, English and Farsi: A case study of multilingualism. Khazar Journal of Humanities and Social Sciences, 19 (3), 60-67. DOI: $\underline{10.5782 / 2223-2621.2016 .19 .3 .60}$

Sperry, R.W. (1981) 'Some Effects of Disconnecting the Cerebral Hemispheres' America.

Wikimedia Commons (2016) Biology. Available from: https://commons.wikimedia.org/wiki/File:Figure 35_03 03.png. [Accessed 18th January 2020]. 